\title{
Large-scale gene expression studies of the endometrium: what have we learnt?
}

\author{
Rob Sherwin, Rob Catalano ${ }^{1}$ and Andrew Sharkey ${ }^{1}$ \\ Department of Obstetrics \& Gynaecology, The Rosie Hospital, Robinson Way, Cambridge CB2 2SW, UK and \\ ${ }^{1}$ Department of Pathology, Tennis Court Road, Cambridge CB2 1QP, UK \\ Correspondence should be addressed to A M Sharkey; Email: as168@cam.ac.uk
}

\begin{abstract}
The endometrium is a dynamic tissue that undergoes coordinated changes under the influence of steroid hormones. This results in proliferation and differentiation culminating in a receptive state, followed by menstruation and endometrial repair. These functions involve complex interactions between the epithelium, stroma and leucocytes in the endometrium. Understanding the underlying causes of endometrial disorders, such as infertility, endometriosis and heavy menstrual bleeding, therefore represents a considerable challenge. Recently developed techniques, such as differential display and DNA microarrays permit the abundance of thousands of mRNA transcripts within cells or tissues to be measured simultaneously. This provides a new approach to understanding the complex interactions that underlie both healthy and disease states. Responses of the endometrium to hormones or drugs can be studied and the response of the system as an integrated whole can be assessed.

Comparisons of endometrium from healthy women and those with endometrial dysfunction have advanced our understanding of key areas of endometrial physiology, including infertility, receptivity, endometriosis and cancer. Using this approach, novel genes controlling specific endometrial functions like receptivity have been identified for functional testing. This paper will review the impact of these techniques for transcript profiling on our understanding of selected areas of endometrial biology and discuss the potential applications in future.
\end{abstract}

Reproduction (2006) $1321-10$

\section{Introduction}

In preparation for embryo implantation, endometrium responds to ovarian sex steroids by undergoing a dynamic series of morphological, biochemical and molecular changes. The endometrium is a complex tissue with distinct cellular compartments. Luminal epithelium provides a defensive barrier and is also the site of embryo attachment. The glandular epithelium secretes paracrine and autocrine factors and the stroma undergoes decidualisation to support and regulate trophoblast invasion. The many cell types within these compartments (epithelial, stromal and endothelial cells as well as leukocytes) are influenced not only by the hormonal milieu, but also by paracrine messengers secreted by the neighbouring cells. Genomic techniques have provided a powerful set of tools for understanding the transcriptional changes that occur in this complex tissue. They have permitted the investigation of both normal cyclical changes as well as the study of disease states, such as menorrhagia, endometriosis and endometrial cancer. This paper will review how these techniques have been used so far to study endometrial biology and what they have revealed, with particular emphasis on the studies of endometrial receptivity.

Several genomic techniques have been developed to identify differential mRNAs, expressed at different levels between the two RNA samples. Estimates vary as to how many of the projected 30000 human genes are expressed in any one cell type, but in most tissues, 50\% of mRNA by mass is comprised of only $300-500$ of the most abundant genes (Bishop et al. 1974, Axel et al. 1976). Therefore, when choosing a genomic technique to interrogate endometrial gene expression, the sensitivity of the technique (ability to differentiate between two transcriptomes that vary only in low-abundance transcripts) as well as the reproducibility, cost and ease of use, must be considered. Examples of the most commonly used genomic techniques are given in Table 1. Of these possible approaches, differential display (DD)-based methods and more recently, DNA microarrays have been most widely used in the study of endometrial biology. 
Table 1 Classification of genomic techniques.

\begin{tabular}{ll}
\hline Classification & Examples \\
\hline $\begin{array}{l}\text { Hybridisation techniques } \\
\text { Differential colony hybridisation }\end{array}$ & $\begin{array}{l}\text { Colony filters } \\
\text { PCR product macro/ } \\
\text { microarrays } \\
\text { Microarrays, } \\
\text { oligonucleotide arrays }\end{array}$ \\
Glass arrays & $\begin{array}{l}\text { Suppression subtractive } \\
\text { hybridisation }\end{array}$ \\
$\begin{array}{l}\text { Subtractive techniques } \\
\text { Subtractive hybridisation }\end{array}$ & \\
Representational difference analysis & \\
Enzymatic degrading subtraction & \\
Gel based techniques & Profiling, indexing, gene \\
RNA arbitrarily primed (RAP-PCR) & expression fingerprinting \\
Differential display (DD) & \\
Sequencing based techniques & \\
Expression sequence tags & \\
Serial analysis of gene expression (SAGE) & \\
\hline
\end{tabular}

\section{DD-based techniques}

The general principle of DD methods is to amplify partial cDNA sequences from a subset of mRNAs, by RT and PCR (Liang \& Pardee 1992). cDNA synthesis is performed using a set of oligo-dT nucleotides that have at their $3^{\prime}$ end, two other bases (e.g. tttttttttca). These oligonucleotides anchor the polyadenylate tail of a subset of 1/12th of all the mRNAs. PCR amplification of this subset is performed using short primers (6-7 nucleotides) of arbitrary sequence, to bind upstream of the poly-A tail. This results in radiolabelled-cDNA fragments of varying lengths that can then be resolved

Reproduction (2006) 132 1-10
Isolate total RNA on day $4 \mathrm{pc}$ from uteri of pseudopregnant LIF +/+ (fertile) and LIF -/- (infertile) females
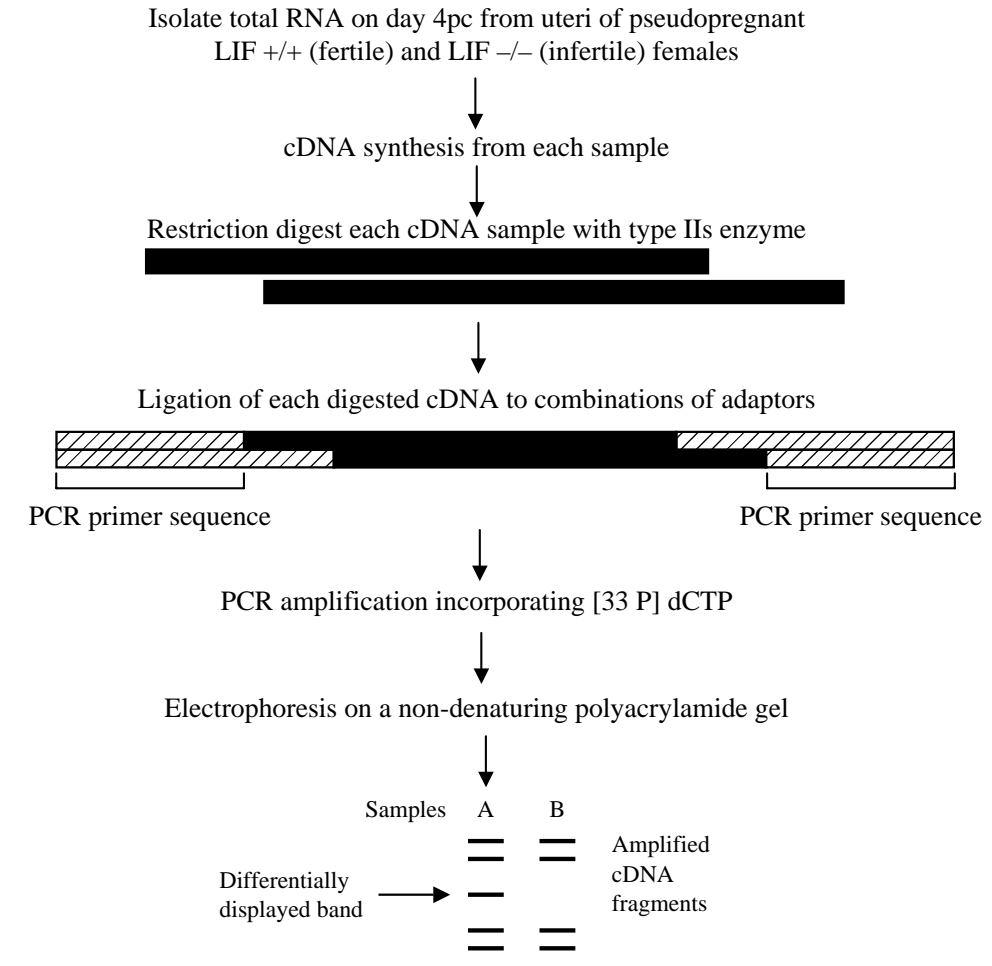

by gel electrophoresis and visualised by autoradiography. Side-by-side comparison of mRNA species from two or more related samples allows the identification of cDNAs that are up- or downregulated. Variations of the original DD technique have been developed, with the aim of reducing the number of false-positive candidates. One of these technical variations is indexing, which involves the synthesis of short cDNA termination products by PCR amplification, using a set of oligonucleotide primers, in multiple reactions (see Figs 1 and 2). This produces a subset of 10-60 bands of amplified cDNAs (the profile or index), allowing a comparison between two mRNA populations. The falsepositive rate using this technique is said to be greatly reduced compared to the conventional DD (Mahadeva et al. 1998).

A strength of DD is that it allows novel transcripts to be identified, but it suffers from a high rate of false positives (Liang \& Pardee 1995, Sompayac et al. 1995), as well as a bias towards high copy number mRNAs (Bertioli et al. 1995). This may make DD an inappropriate choice of technique in systems, where only a few mRNA species are expected to differ (Sompayac et al. 1995). However, a number of endometrial biologists have successfully used this technique (Table 2). Okulicz identified several progesterone-regulated genes whose expression in primate endometrium is limited to the window of implantation (Okulicz et al. 2003). This experiment highlights the strength of DD in that half of the genes identified were novel expression sequence tags. Several new groups of
Figure 1 Schematic representation of the steps involved in a cDNA indexing study to compare RNA samples from two different tissues. 


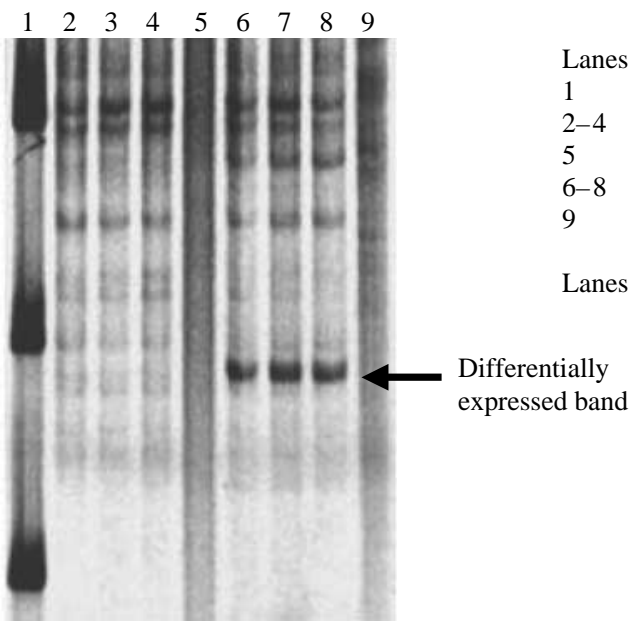

genes were identified and shown to be regulated by progesterone in endometrium. Similarly, Nie and colleagues. in a series of experiments using DD (Nie et al. 2000a, b,c), used it to compare the endometrial gene expression on day 4 of pregnancy, at implantation and intersite locations in the mouse. This led to the identification of the calbindin family of proteins, as being specifically upregulated at the site of embryo attachment. In subsequent experiments, they showed that functional blockade of the calbindins, CaBP-d9k and CaBP-d28k, successfully prevents implantation (Nie et al. 2000c, Luu et al. 2004). These regulators of calcium homeostasis clearly play an important role in the process of implantation. Other genes identified in this series of mouse experiments included proprotein convertase-6 (PC6), an endoprotease that cleaves inactive precursors into active molecules ( $\mathrm{Nie}$ et al. 2003). PC6 was shown to be expressed in the stroma beneath the implantation site in the mouse and when expression was inhibited by anti-sense morpholinos, complete functional blockade of the implantation process was achieved. These examples show that genes with important functions in endometrial biology can be identified using this technique. However, DD is slow and labour intensive and does generate a high number of false-positive candidates. More recently, DD has been superseded by other techniques, such as suppression subtractive hybridisation and microarraybased investigations. Selected examples of these techniques and their use in endometrium are given in Table 2.

\section{Array-based studies}

Array-based expression studies followed from the work of Southern and others (Gillespie \& Spiegelman 1965, Southern 1974) requires the hybridisation of complementary strands of DNA or RNA onto an ordered grid of DNA, which is arrayed on a glass or nylon support. The arrayed DNA sequences are usually mechanically
Figure 2 cDNA indexing comparison of the uterine transcriptome, at $96 \mathrm{~h}$ of pseudopregnancy, between a leukaemia inhibitory factor (LIF) wild-type (LIF +/+) animal and a LIF null mutant (LIF - /-) animal. Aliquots of doublestranded cDNA, digested with FOK1, a type-II restriction enzyme and ligated to a mixture of 32 adaptors, was amplified by PCR, in which ${ }^{33} \mathrm{P}$ was incorporated. The amplified products were electrophoresed and transferred on to a filter paper. The dried gels were exposed to phosphorimager screens and then X-ray film. Three aliquots of each adaptor ligated cDNA sample were amplified and electrophoresed. A single aliquot of minus-RT 'CDNA' (cDNA 'synthesised' without reverse transcriptase) was amplified to act as a control for genomic contamination of each cDNA sample. Results from amplification with a single primer pair are shown. A clear, differentially expressed band was identified which is upregulated in LIF-/uterine cDNA. spotted and are either oligonucleotides between 20 and $80 \mathrm{bp}$ or cDNAs of several hundred base pairs. In some cases, the DNA arrays are manufactured by synthesising oligonucleotide spots in situ onto the glass surface of the array. Fluorescent or radiolabelled complex probes are prepared from mRNA, isolated from cells or tissues of interest. After hybridisation of these complex probes to the array, the signal generated by the hybridisation of each specific cDNA species, to its complementary array sequence, can be measured with a confocal laser scanner. cDNAs from two sources can also be compared by labelling complex probes from the two samples with different colour fluorophores (such as Cy3-green and Cy5-red). These probes can then be hybridised simultaneously to the same microarray and the signal from each hybridised fluoroprobe measured. One of the major hurdles in the use of microarrays is the analysis of the raw hybridisation data (Gaasterland \& Bekiranov 2000). Appropriate mathematical transformation to normalise the data is essential to account for experimental and biological variation. This is one of the major causes of error and difference between laboratories, since the statistical approaches used can greatly affect the outcome. If the same raw data from an array experiment is analysed, using different statistical methods, there can be major differences in the number of genes identified as altered.

The results of microarray experiments are most frequently reported as a fold difference; for example, a gene transcript may be reported as increased threefold in expression level between secretory and proliferative endometrium. Such an approach can be highly misleading as hybridisation signals obtained for genes expressed at low levels show greater variation than genes expressed at high levels due to experimental error and background noise. Therefore, a tenfold change in expression of a gene expressed at low levels may be less easily validated in subsequent experiments than a gene that shows a twofold change, 
Table 2 Examples of large scale endometrial gene expression studies.

\begin{tabular}{|c|c|c|c|c|}
\hline Biology studied & Technique used & $\begin{array}{l}\text { No. of genes } \\
\text { studied }\end{array}$ & Biological material used & Reference \\
\hline \multirow[t]{5}{*}{ Endometriosis } & Atlas Nylon array & 597 & Primary stromal cells treated with IL-1 $\beta$ & (Lebovic et al. 2002) \\
\hline & Affymetrix array & 12686 & $\begin{array}{l}\text { Eutopic endometrial biopsies from women with } \\
\text { and without endometriosis }\end{array}$ & (Kao et al. 2003) \\
\hline & Nylon array & 4133 & Eutopic vs ectopic biopsies & (Eyster et al. 2002) \\
\hline & $\begin{array}{l}\text { Research genetics cDNA } \\
\text { array }\end{array}$ & 9600 & Eutopic vs ectopic biopsies & (Wu et al. 2006) \\
\hline & Glass slide cDNA array & 23000 & Eutopic vs ectopic biopsies & (Arimoto et al. 2003) \\
\hline \multirow[t]{15}{*}{ Endometrial receptivity } & DD & & Mouse implantation and intersite & (Nie et al. 2000b) \\
\hline & DD & & Receptive vs non-receptive primate endometrium & (Okulicz et al. 2003) \\
\hline & Subtractive hybridisation & & Rat implantation and intersite & (Simmons \& Kennedy 2002) \\
\hline & Affymetrix array & 10000 & $\begin{array}{l}\text { Implantation and intersite from day } 4 \text { mice } \\
\text { Delayed implantation with or without } \mathrm{P}_{4}\end{array}$ & (Reese et al. 2001) \\
\hline & Affymetrix array & 6500 & Uteri from day 3.5 and day 5 mice & (Yoshioka et al. 2000) \\
\hline & Affymetrix array & 6000 & $\begin{array}{l}\text { Uteri from mice treated on day } 3 \text { with RU } 486 \text { or } \\
\text { control }\end{array}$ & (Cheon et al. 2002) \\
\hline & Custom array & 5000 & $\begin{array}{l}\text { Ovariectomised cynomologus monkeys, treated } \\
\text { with oestrogen and RU486 }\end{array}$ & (Tynan et al. 2005) \\
\hline & Custom nylon array & 1000 & Endometrial explants treated with RU 486 & (Catalano et al. 2003) \\
\hline & Affymetrix array & 60000 & Pooled endometrial biopsies & (Borthwick et al. 2003) \\
\hline & Affymetrix array & 12000 & $\begin{array}{l}\text { Five paired endometrial } \\
\text { biopsies at } \mathrm{LH}+2 \text { and } \mathrm{LH}+7 \text { from the same } \\
\text { women }\end{array}$ & (Riesewijk et al. 2003) \\
\hline & Atlas Nylon array & 1176 & $\begin{array}{l}\text { Endometrial cell lines (RL-95-2 and HEC-1-A) and } \\
\text { endometrial biopsies } \mathrm{LH}+2 \text { vs } \mathrm{LH}+7\end{array}$ & (Martin et al. 2002) \\
\hline & Atlas Nylon array & 375 & & (Dominguez et al. 2003) \\
\hline & Affymetrix array & 12000 & $\begin{array}{l}\text { Three early }(\mathrm{LH}+2-4) \text { and three mid secretory } \\
(\mathrm{LH}+7-9) \\
\text { endometrial biopsies }\end{array}$ & (Carson et al. 2002) \\
\hline & Affymetrix array & 12686 & $\begin{array}{l}\text { Endometrial biopsies ( } 10 \text { late proliferative phase } \\
\text { and } 18 \text { from } \mathrm{LH}+8 \text { to } \mathrm{LH}+10 \text { ) }\end{array}$ & (Kao et al. 2002) \\
\hline & Affymetrix array & 12000 & $\begin{array}{l}\text { Endometrial biopsies from day } 13 \text { and days } 21-23 \\
\text { in Rhesus monkeys }\end{array}$ & (Ace \& Okulicz 2004) \\
\hline $\begin{array}{l}\text { Endometrial and } \\
\text { trophoblast interactions }\end{array}$ & DD & & Stromal cells cultured with BeWo cell line & (Cowan et al. 1999) \\
\hline \multirow[t]{6}{*}{ Decidualisation } & Atlas Nylon array & 588 & $\begin{array}{l}\text { Primary culture of stromal cells treated with } \\
\text { progesterone and cAMP }\end{array}$ & (Popovici et al. 2000) \\
\hline & Affymetrix array & 12686 & Primary culture of stromal cells treated with cAMP & (Tierney et al. 2003) \\
\hline & Atlas array & 1176 & Primary culture of stromal cells & (Okada et al. 2000) \\
\hline & Atlas array & 1000 & $\begin{array}{l}\text { Primary culture of stromal cells treated with } \\
\text { progesterone }\end{array}$ & (Okada et al. 2003) \\
\hline & Custom microarray & 9600 & Decidua and first trimester trophoblast & (Chen et al. 2002) \\
\hline & Incyte GEM-V array & 6918 & Primary culure of stromal cells & (Brar et al. 2001) \\
\hline \multirow[t]{8}{*}{ Endometrial cancer } & Atlas Nylon array & 588 & $\begin{array}{l}\text { Ishikawa cell lines transfected with PRA and PRB, } \\
\text { treated with progestins }\end{array}$ & (Smid-Koopman et al. 2003) \\
\hline & $\mathrm{NCl}$ microarray & 9984 & Endometrial cancer biopsies & (Risinger et al. 2003) \\
\hline & Atlas array & 588 & Endometrial cancer vs normal endometrium & (Meng et al. 2001) \\
\hline & Microarray & 4096 & Endometrial cancer vs normal endometrium & (Zhou et al. 2003) \\
\hline & Atlas Nylon array $x 2$ & $1176 \& 588$ & $\begin{array}{l}\text { Hec50 cell line transfected with PRA and PRB, } \\
\text { treated with progesterone }\end{array}$ & (Dai et al. 2002) \\
\hline & Atlas Nylon array & 1176 & $\begin{array}{l}\text { Normal endometrial epithelial cells treated with } \\
\text { oestrogen and norethisterone }\end{array}$ & (Oehler et al. 2002) \\
\hline & Custom array & 4009 & $\begin{array}{l}\text { Endometrial cancer cell lines }(n=14) \text {, transfected } \\
\text { with PTEN tumour suppressor }\end{array}$ & (Matsushima-Nishiu et al. 2001) \\
\hline & Affymetrix array & 6000 & Endometrial cancer vs normal endometrium & (Mutter et al. 2001) \\
\hline
\end{tabular}

but is highly expressed. Secondly, statistical significance and biological significance are not clearly related. A gene which changes tenfold in expression levels is not necessarily of more biological significance than the one which changes twofold. Interpretation of microarray data is therefore not straightforward.

\section{The use of arrays to identify genes involved in endometrial receptivity}

Successful implantation requires the simultaneous development of both, a competent blastocyst and a receptive endometrium, under the influence of ovarian 
steroids. However, the molecular mechanisms by which endometrium becomes receptive remain unclear. Two approaches have been used to identify genes regulated by progesterone in the endometrium. The first has been to compare proliferative and secretory phase endometrium, to identify global gene expression changes between the oestrogen- and progesterone-dominated phases of the cycle. Kao et al. (2002), Borthwick et al. (2003) compared gene expression in late proliferative and mid-secretory endometrium. The latter study pooled RNA from five samples at each time point, whereas Kao hybridised samples individually. Both these studies used Affymetrix oligonucleotide arrays and so the results can be compared directly. Borthwick showed that 90 transcripts were significantly upregulated and 59 downregulated, between the pooled, proliferative and secretory phase samples. Using different analysis criteria, Kao and colleagues reported 116 upregulated genes and 224 downregulated (Kao et al. 2002). Approximately $30 \%$ of the genes were common to both studies. Differences between the lists are likely to be due to the very different methods of analysing the data generated by the same microarray platform, as well as the use of pooled vs separate samples.

A second approach has been used in two studies, where the effect on transcript expression of RU486, a progesterone receptor (PR) antagonist, has been assessed. This drug binds to the PR and blocks the action of progesterone. Cheon et al. (2002) compared uterine RNA isolated on day 4 of pregnancy from mice treated with RU486 and uterine RNA from normal animals. Using Affymetrix microarrays, 78 known genes were identified as downregulated more than twofold and 70 were upregulated following the RU486 treatment. Independent verification by northern blot of ten of these candidate genes, confirmed their upregulation by progesterone. Only 4 of the 70 genes upregulated by progesterone were previously known to be hormonally regulated. Secondly, some genes that are known to be on the array and progesterone regulated in murine endometrium, such as Hoxa10 and calcitonin, were not detected. The failure to detect these genes probably reflects an expression level below the detection threshold of the array.

In women, a single dose of RU486 (mifepristone) in the secretory phase of the menstrual cycle, rapidly renders the endometrium unreceptive (Danielsson et al. 2003). We have recently used microarrays to examine changes in endometrial gene expression following RU486 administration during the implantation window (Catalano et al. 2003). Pipelle biopsies taken from the endometrium at 6 or $24 \mathrm{~h}$ after RU486 administration on $\mathrm{LH}+8$ were analysed. At $6 \mathrm{~h}$ after RU486, 6 genes were found to be significantly upregulated and 90 were downregulated compared to controls (Sharkey et al. 2005). Although RU486 can affect glucocorticoid and androgen receptor function, the majority of these genes are likely to be directly progesterone regulated. This clearly shows how microarrays can be used in vivo, to study drug action on the endometrium.

A major challenge when faced with these long lists of genes, regulated by progesterone is to identify which of the genes perform an essential role in implantation and which do not. Cheon et al. (2002) demonstrated the value of their microarray analysis by showing that leukocyte 12/15 lipoxygenase (Alox15) is essential for implantation. Alox15 was found to be upregulated by progesterone using microarrays. It acts as a lipidmetabolising enzyme that generates hydroxy-eicosatetraenoic acid (HETE), a signalling molecule, which controls cell differentiation. Cheon et al. (2002) showed that Alox15 is expressed in the luminal epithelium at the time of implantation. Administration of an inhibitor (AA-861) to block Alox15 activity in the uterus reduced implantation by $80 \%$ (Li et al. 2004). Administration of rosaglitazone, an agonist for the proliferation-activated receptor- $\gamma($ PPAR $\gamma)$, restored implantation in mice pretreated with AA-861. This suggests that metabolites generated by Alox15, like 12-HETE, function as activating ligands of PPAR $\gamma$ and thus PPAR $\gamma$ is a downstream target of metabolites generated by Alox15 (Fig. 3). This array-based study also identified other progesterone-regulated genes, whose activity in endometrium had previously been unsuspected. Glutathione peroxidase- 3 and manganese superoxide dismutase protect against cellular damage by reactive oxygen species. Along with a number of metallothionine proteins, these molecules may protect the preimplantation embryo against damage by oxygen radicals and heavy metal toxicity.

Many studies have also been performed comparing prereceptive and receptive murine or human endometrium, with the aim of identifying a 'molecular signature' characteristic of a receptive endometrium. The murine studies have used several different paradigms to identify receptivity genes. These include comparisons of: implantation vs intersite tissue (whole uterus (Nie et al. $2000 b$ ) or luminal epithelium only (Yoon et al. 2004)), prereceptive vs receptive uterus (Yoshioka et al. 2000) and delayed vs nidatory oestrogen-treated uteri (Reese et al. 2001). The ability of microarrays to analyse thousands of mRNAs simultaneously provides a powerful new approach to the identification of markers of receptivity. In women, under the influence of progesterone, endometrium becomes receptive from about day $\mathrm{LH}+5$ to $\mathrm{LH}+10$. Morphological changes (Noyes et al. 1950) and more recently, molecular markers (Ponnampalam et al. 2004) have been identified that are expressed at different stages of the luteal phase. These provide a novel means to assess whether normal endometrial development is occurring.

Several studies have sought to identify new markers of the receptive state using array-based technology. Endometrium from patients with endometriosis or 


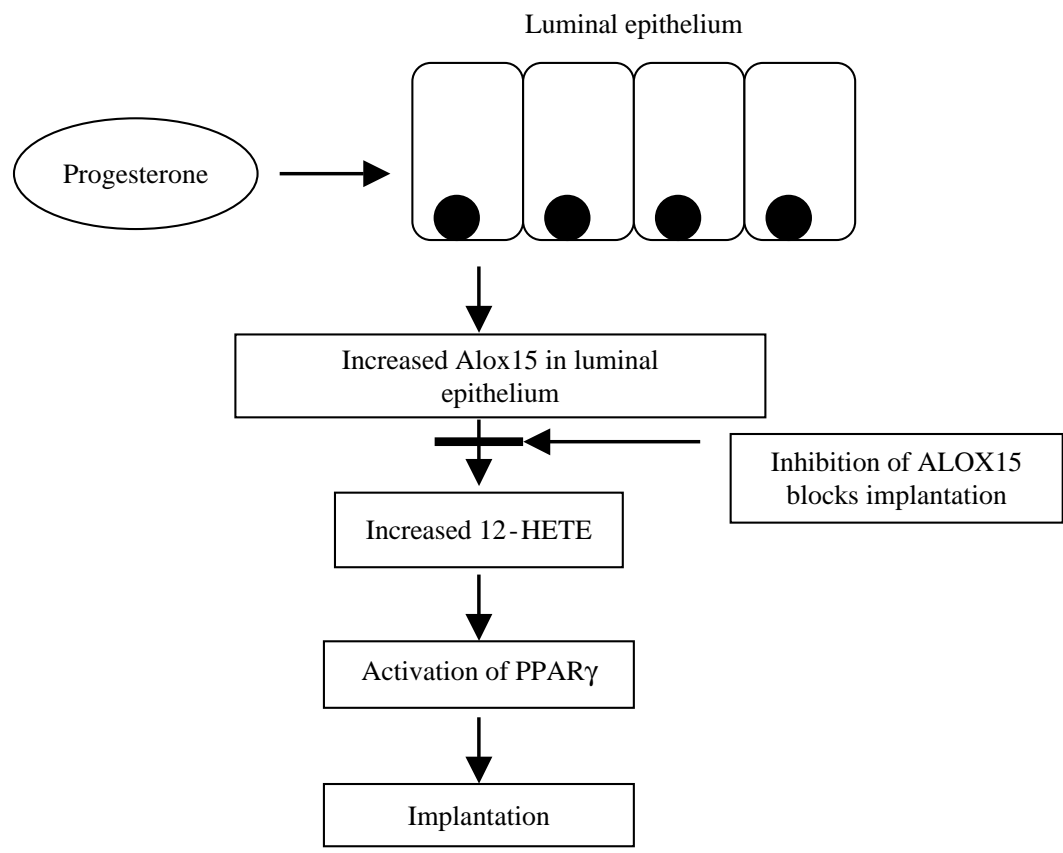

Figure 3 Using microarrays, the enzyme ALOX15 has been identified as essential for implantation in murine endometrium. ALOX15 is upregulated in the luminal epithelium by progesterone. This results in increased synthesis of 12-HETE, which in turn activates PPAR $\gamma$. Inhibition of ALOX15 activity results in implantation failure. unexplained infertility, when compared to endometrium from women with a past history of fertility, shows a number of changes in the transcriptome, which may be of functional significance (Giudice et al. 2002). However, there is substantial overlap in expression levels of these markers between subfertile patients and normal controls and so clinically, the predictive value of any one of these molecular markers is low (Damario et al. 2001). Two studies have compared gene expression in women with a past history of fertility on days $\mathrm{LH}+2$ (prereceptive) and $\mathrm{LH}+7$ (receptive). Carson et al. (2002) compared three biopsies at each time point, taken from different women, whereas Riesewijk et al. (2003) compared paired biopsies taken from the same women $(n=5)$ at two time points. The first study identified 370 transcripts as upregulated and 323 downregulated by at least twofold, whereas Riesewijk identified 153 genes as upregulated and 58 as downregulated by an average of threefold or more. More significantly, many new genes were identified to show regulation, a large number of which had not been previously shown to even be expressed in endometrium. For example, members of the Wnt family of signalling molecules and related inhibitors were identified for the first time in endometrium and may play a role in epithelial/stromal interactions during the receptive phase (Tulac et al. 2003). Indeed in mice, uterine Wnt signalling has recently been shown to be essential for implantation (Mohamed et al. 2005).

Although there is a substantial overlap in the gene lists generated from the array experiments examining secretory phase endometrium, they are not identical. There are a number of explanations for this and it is important to appreciate the limitations of array-based interrogation.
First, in designing the study, it is necessary to select welldefined populations for comparison (in this case $\mathrm{LH}+2$ and $\mathrm{LH}+7$ ). Secondly, samples may be pooled at each time point prior to hybridisation (Borthwick et al. 2003) or hybridised separately (Kao et al. 2002). Pooling the samples reduces the cost of the experiment and gives a biological average, but reduces the power of the post-array statistical analysis and does not allow exclusion of 'unusual or untypical' samples that may reflect outliers. Subtle differences in the analysis criteria, like the choice of data normalisation methods or gene selection criteria may also account for large differences in the gene lists generated, e.g. average change of threefold (Carson et al. 2002) or twofold (Riesewijk et al. 2003). Finally, these studies involved very small patient groups ( $n=3$ or 5 ). With such small groups, the biological variation between patients due to genotypic and environmental differences may substantially influence the final gene lists. In genetically identical inbred mice, housed under identical environmental conditions, microarray studies of kidney transcript abundance showed that $3.3 \%$ of RNA transcripts exhibited altered expression over and above what could be explained by technical variation between arrays (Pritchard et al. 2001). In a microarray experiment, which examined 12000 genes, this amounts to a substantial number of false positives that may have little biological relevance. Thus, the need for rigorous and robust experimental design and careful consideration of the data analysis is essential to reduce false positives (Stafford \& Liu 2003). Validation of candidate gene expression changes using northern blotting or quantitative PCR is essential. The correlation of transcript abundance change with changes in the corresponding protein, followed by functional testing of the 
biological effect of that protein, allows the biological significance of the microarray changes to be confirmed.

\section{The use of microarrays in the study of endometriosis}

Endometriosis is characterised by the presence of endometrial tissue at ectopic sites, typically within the pelvis and the ovary. It is associated with pelvic pain and subfertility. A recent microarray study of gene expression in luteinising hormone ( $\mathrm{LH})$-timed $(\mathrm{LH}+8$ to 10$)$ biopsies of eutopic endometrium from normal fertile women $(n=7)$ and women with endometriosis $(n=8)$, identified 91 upregulated and 115 downregulated genes (Kao et al. 2003). Functional classification of these revealed genes involved in cell adhesion, apoptosis, signal transduction and also some secreted proteins. The majority had not previously been shown to be dysregulated in endometriosis and may provide new insights into the subfertility in women with endometriotic disease that does not involve the fallopian tube or ovarian function. One such candidate is $\mathrm{S} 100 \mathrm{E}$, a member the calciumbinding family of proteins, whose expression is reduced in eutopic endometrium of women with endometriosis. Mice carrying a null mutation of a closely related protein, S100A8, are infertile due to an implantation failure (Passey et al. 1999). Downregulation of the calcium-binding protein, calbindin $\mathrm{d} 9 \mathrm{~K}$, using antisense oligonucleotides also prevents implantation (Luu et al. 2004). Taken together, these results imply a critical role for calcium homeostasis in normal implantation. There is now a wealth of data studying both individual genes and using microarray methods that show differences in gene expression between normal and eutopic endometrium from women with endometriosis (reviewed in Wu et al. 2006). These authors performed microarray analysis of eutopic and ectopic endometrium from the same patient using samples obtained by laser capture microdissection (LCM). They identified over 100 genes with known functions that differed between the two. An unresolved question is whether the differences in eutopic endometrium are caused by the presence of ectopic endometrium in the peritoneum or whether they pre-date the establishment of endometriosis. The gene, CYR61, is one of those which show increased expression in eutopic endometrium in women with endometriosis, compared with normal women (Absenger et al. 2004). Using the baboon model in which endometriosis can be induced in the peritoneum, Gashaw et al. (2006) showed that expression of CYR61 is induced in eutopic endometrium of animals with induced endometriosis, within a month of inoculation of menstrual tissue in the menstrual cavity. This provides evidence for a feedback mechanism from the resulting lesions that can induce changes in the geneexpression patterns in the eutopic endometrium. An outstanding question, therefore, is which of the alterations seen in eutopic endometrium of women with endometriosis is induced by the presence of peritoneal lesions and which pre-date the development of endometriosis and may hence contribute to the pathogenesis of the disease.

\section{Expression profile analyses of endometrial cancer}

One of the most valuable potential uses of microarrays is their use in the classification of endometrial cancers (Mutter et al. 2001, Risinger et al. 2003). These studies have shown that microarrays provide a powerful approach for identifying therapeutic targets. They have also generated a list of candidate biomarker genes that provide discrimination between normal and malignant tissues, and different tumour types. Endometrial cancers are characterised by mutations of PTEN, KRAS2 and CTNNB1 (type I) or TP53 and Her-2/neu (type II), although as $50 \%$ of endometrial cancers lack these mutations, it is likely that there are unrecognised pathways that are mutagenic. Holland et al. (2004) used microarrays to identify peroxisome proliferatoractivated receptor- $\alpha(\operatorname{PPAR} \alpha)$ as a potential therapeutic target in endometrial cancer treatment. Treatment of an endometrial cancer cell line with a PPAR $\alpha$ agonist, significantly reduced proliferation and increased cell death, suggesting that altered expression of nuclear hormone receptors involved with fatty acid metabolism may lead to deregulated cellular proliferation and apoptosis. Risinger et al. (2003) used cDNA microarrays to compare gene expression in endometrioid and nonendometrioid cancers to normal endometrium. Unsupervised multidimensional scaling revealed separate clusters for papillary serous, clear cell and endometrioid cancers compared with normal endometrium. This indicates consistent global gene expression changes for each cancer type. Hierarchical clustering using the genes that statistically differed between one or more of the four subgroups, showed that gene expression differences in only 24 transcripts could distinguish serous from endometriotic cancers. These arrays also revealed previously unrecognised novel pathways in endometrial cancers, such as the downregulation of SOCS2, a member of the suppressors of cytokine signalling family of intracellular proteins that are involved in the negative regulation of cytokine signal transduction.

Microarrays have been used to investigate the molecular effects of progesterone, which is known to reduce the risk of developing endometrial cancer, and PRs are found in endometrial cancer cells (Dai et al. 2002, Oehler et al. 2002, Smid-Koopman et al. 2003). After treatment of normal, non-transformed endometrial epithelial cells with oestradiol and the synthetic progestogen norethisterone acetate, $\mathrm{Wnt}-7 \mathrm{a}$, part of the Wnt family of secreted signalling molecules, was shown to be upregulated (Oehler et al. 2002). Wnt signalling, therefore, may be involved in the anti-neoplastic, endometrial protective effects of progestogens. 
Two studies have examined the functional difference between the two human progesterone receptor (hPR) isoforms in human endometrial cancer (Dai et al. 2002, Smid-Koopman et al. 2003). Endometrial cancer cell lines, stably transfected with either hPRA or hPRB, were treated with progestins and differential gene expression was analysed using nylon cDNA arrays. The array data revealed distinctive differences in target gene regulation between the two hPR isoforms. Only cells expressing hPRB were growth responsive to progesterone and expression levels of five different genes, insulin-like growth factor-binding protein-3, fibronectin and replication protein A (Smid- Koopman et al. 2003) and fibronectin, integrin $\alpha_{3} \beta_{1}$ (Dai et al. 2002) were downregulated in hPRB-expressing cells. The results emphasised that the relative distribution of hPRA and hPRB in endometrial cancer cells may have great implications on the behaviour of human endometrial tumours. Downregulation of adhesion molecules in the presence of the hPRB isoform suggests that progesterone acts principally through hPRB receptors to inhibit cancer cell invasiveness mediated by adhesion molecules (Dai et al. 2002).

\section{The future of large-scale studies of endometrial gene expression}

To date, microarrays have been the primary method employed in large-scale studies of gene expression in endometrium. They have been used in two main ways. The first is the comparison of tissue from normal women and patient groups. Examples include comparisons of normal and malignant tissue, or endometrium from normal women and those with endometriosis. The aim here is to identify changes in gene expression, characterising the disease state, to understand disease progression and to identify novel therapeutic targets. In cancer, careful expression profiling can distinguish different closely related tumour types and may lead to tailoring of subsequent clinical management, based on the molecular phenotype of the tumour and the likely prognosis. In future, such studies will be extended to other areas of endometrial dysfunction such as menorrhagia and unexplained infertility. Secondly, microarrays have been used to study the actions of hormones, cytokines and drugs on endometrium. Experiments to identify genes regulated by progesterone have been very successful in expanding our understanding of how this hormone or antagonists like RU486, act on endometrium. It has also led to the identification of novel therapeutic targets, for example, in the area of contraception (Alox15).

A weakness of most of these studies is their use of whole tissue samples, which means that genes expressed at low levels in a limited number of cells may not be detected. A second limitation is that if a gene is expressed in different cell types at different levels, only an average read-out is detected by microarray analysis of the whole tissue. In order to understand the responses of individual endometrial compartments, and how they may influence each other, it will be necessary to isolate individual cell types to determine their unique transcriptome. One solution to this problem is the technique of LCM, which has recently been used to study luminal gene changes induced by blastocyst apposition (Yoon et al. 2004). In this approach, individual cells or groups of cells such as luminal or glandular epithelium can be isolated under the microscope from tissue sections and RNA from them interrogated by microarrays. This allows a gene-expression profile specific to one cell type to be determined. An example of laser capture on murine endometrium is shown in Fig. 4. Preliminary studies using this technique have shown that it holds considerable promise to improve our understanding of the interactions between different cellular compartments in endometrium (Yanaihara et al. 2005). Although microarray techniques have become extremely powerful tools, many cellular functions require alterations in proteins that are not reflected in steady-state RNA levels. The development of high throughput 'proteomic' techniques is underway and these potentially offer the ability to examine effects of post-translational regulation of protein expression levels. Post-translational modification such as ubiquitination and phosphorylation also play major roles in regulating protein functions such as halflife and enzyme activity. These aspects of the cell biology of the endometrium can only be investigated by high throughput protein-based methods. A complete understanding of endometrial function will require integration of RNA data from microarray experiments with protein data from other techniques.

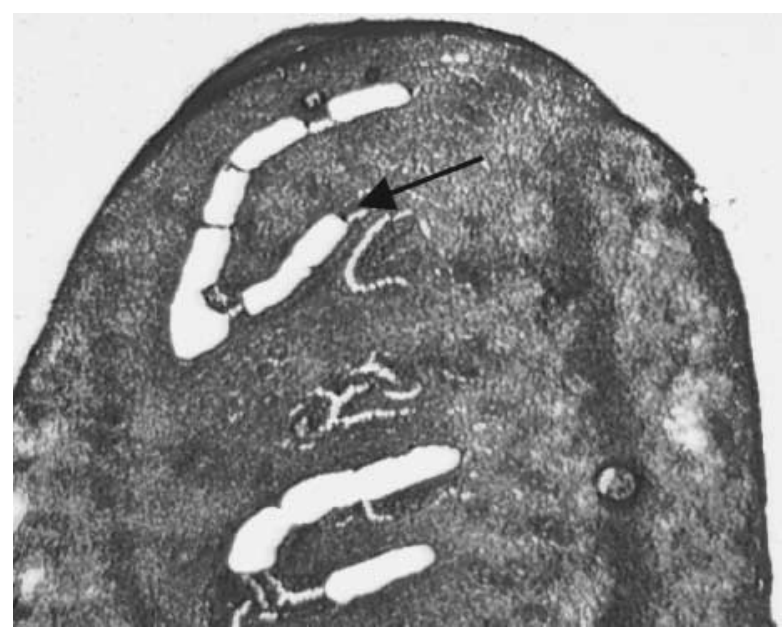

Figure 4 Laser capture microdissection of murine endometrium. Frozen sections of mouse uterus at day 3 of pregnancy were subjected to laser capture microdissection using a PALM MicroBeam system. Luminal epithelium (arrowed) was collected for RNA isolation and microaray hybridisation without stromal cells. The region from which the epithelium has been collected is clearly visible. 


\section{References}

Arimoto T, Katagiri T, Oda K, Tsunoda T, Yasugi T, Osuga Y, Yoshikawa H, Nishii O, Yano T, Taketani Y \& Nakamura Y 2003 Genomewide cDNA microarray analysis of gene-expression profiles involved in ovarian endometriosis. International Journal of Oncology 22 551-560.

Absenger $Y$, Hess-Stumpp H, Kreft B, Kratzschmar J, Haendler B, Schutze N, Regidor PA \& Winterhager E 2004 Cyr61, a deregulated gene in endometriosis. Molecular Human Reproduction 10 399-407.

Ace CI \& Okulicz WC 2004 Microarray profiling of progesteroneregulated endometrial genes during the rhesus monkey secretory phase. Reproductive Biology and Endocrinology 254.

Axel R, Feigelson P \& Schutz G 1976 Analysis of the complexity and diversity of mRNA from chicken liver and oviduct. Cell 7 247-254.

Bertioli DJ, Schlichter UH, Adams MJ, Burrows PR, Steinbiss HH \& Antoniw JF 1995 An analysis of differential display shows a strong bias towards high copy number mRNAs. Nucleic Acids Research 23 4520-4523.

Bishop JO, Morton JG, Rosbash M \& Richardson M 1974 Three abundance classes in HeLa cell messenger RNA. Nature 250 199-204.

Borthwick JM, Charnock-Jones DS, Tom BD, Hull ML, Teirney R, Phillips SC \& Smith SK 2003 Determination of the transcript profile of human endometrium. Molecular Human Reproduction $\mathbf{9}$ 19-33.

Brar AK, Handwerger S, Kessler CA \& Aronow BJ 2001 Gene induction and categorical reprogramming during in vitro human endometrial fibroblast decidualization. Physiological Genomics (Online) 7 135-148.

Carson DD, Lagow E, Thathiah A, Al-Shami R, Farach-Carson MC, Vernon M, Yuan L, Fritz MA \& Lessey B 2002 Changes in gene expression during the early to mid-luteal receptive phase transition in human endometrium detected by high-density microarray screening. Molecular Human Reproduction 8 871-879.

Catalano RD, Yanaihara A, Evans AL, Rocha D, Prentice A, Saidi S, Print CG, Charnock-Jones DS, Sharkey AM \& Smith SK 2003 The effect of RU486 on the gene expression profile in an endometrial explant model. Molecular Human Reproduction 9 465-473.

Chen HW, Chen JJ, Tzeng CR, Li HN, Chang SJ, Cheng YF, Chang CW, Wang RS, Yang PC \& Lee YT 2002 Global analysis of differentially expressed genes in early gestational decidua and chorionic villi using a 9600 human cDNA microarray. Molecular Human Reproduction 8 475-484.

Cheon YP, Li Q, Xu X, DeMayo FJ, Bagchi IC \& Bagchi MK 2002 A genomic approach to identify novel progesterone receptor regulated pathways in the uterus during implantation. Journal of Molecular Endocrinology 16 2853-2871.

Cowan BD, Hines RS, Brackin MN \& Case ST 1999 Temporal and cellspecific gene expression by human endometrium after coculture with trophoblast. American Journal of Obstetrics and Gynecology 180 806-814.

Dai D, Wolf DM, Litman ES, White MJ \& Leslie KK 2002 Progesterone inhibits human endometrial cancer cell growth and invasiveness: down-regulation of cellular adhesion molecules through progesterone B receptors. Cancer Research 62 881-886.

Damario MA, Lesnick TG, Lessey BA, Kowalik A, Mandelin E, Seppala M \& Rosenwaks Z 2001 Endometrial markers of uterine receptivity utilizing the donor oocyte model. Human Reproduction 16 1893-1899.

Danielsson KG, Marions L \& Bygdeman M 2003 Effects of mifepristone on endometrial receptivity. Steroids 68 1069-1075.

Dominguez F, Avila S, Cervero A, Martin J, Pellicer A, Castrillo JL \& Simon C 2003 A combined approach for gene discovery identifies insulin-like growth factor-binding protein-related protein 1 as a new gene implicated in human endometrial receptivity. Journal of Clinical Endocrinology and Metabolism 88 1849-1857.
Eyster KM, Boles AL, Brannian JD \& Hansen KA 2002 DNA microarray analysis of gene expression markers of endometriosis. Fertility and Sterility 77 38-42.

Gaasterland T \& Bekiranov S 2000 Making the most of microarray data. Nature Genetics 24 204-206.

Gashaw I, Hastings JM, Jackson KS, Winterhager E \& Fazleabas AT 2006 Induced endometriosis in the Baboon Papio anubis increases the expression of the proangiogenic factor CYR61 (CCN1) in eutopic and ectopic endometria. Biology of Reproduction $\mathbf{7 4}$ 1060-1066.

Gillespie D \& Spiegelman S 1965 A quantative assay for DNA-RNA hybrids with DNA immobilised on an membrane. Journal of Molecular Biology 12 829-842.

Giudice LC, Telles TL, Lobo S \& Kao L 2002 The molecular basis for implantation failure in endometriosis: on the road to discovery. Annals of the New York Academy of Sciences 955 252-264; discussion 293-255, 396-406

Holland CM, Saidi SA, Evans AL, Sharkey AM, Latimer JA, Crawford RA, Charnock-Jones DS, Print CG \& Smith SK 2004 Transcriptome analysis of endometrial cancer identifies peroxisome proliferatoractivated receptors as potential therapeutic targets. Molecular Cancer Therapy 3 993-1001.

Kao LC, Tulac S, Lobo S, Imani B, Yang JP, Germeyer A, Osteen K, Taylor RN, Lessey BA \& Giudice LC 2002 Global gene profiling in human endometrium during the window of implantation. Endocrinology $1432119-2138$.

Kao LC, Germeyer A, Tulac S, Lobo S, Yang JP, Taylor RN, Osteen K, Lessey BA \& Giudice LC 2003 Expression profiling of endometrium from women with endometriosis reveals candidate genes for disease-based implantation failure and infertility. Endocrinology 144 2870-2881.

Lebovic DI, Baldocchi RA, Mueller MD \& Taylor RN 2002 Altered expression of a cell-cycle suppressor gene, Tob-1, in endometriotic cells by cDNA array analyses. Fertility and Sterility 78 849-854.

Li Q, Cheon YP, Kannan A, Shanker S \& Bagchi MK 2004 A novel pathway involving progesterone receptor, 12/15 lipoxygenasederived eicosanoids, and peroxisome proliferator-activated receptor gamma regulates implantation in mice. Journal of Biological Chemistry 279 11570-11581.

Liang P \& Pardee AB 1992 Differential display of eukaryotic messenger RNA by means of the polymerase chain reaction. Science 257 967-971.

Liang P \& Pardee AB 1995 Recent advances in differential display. Current Opinion in Immunology 7 274-280.

Luu KC, Nie GY \& Salamonsen LA 2004 Endometrial calbindins are critical for embryo implantation: evidence from in vivo use of morpholino antisense oligonucleotides. PNAS 101 8028-8033.

Mahadeva H, Starkey MP, Sheikh FN, Mundy CR \& Samani NJ 1998 A simple and efficient method for the isolation of differentially expressed genes. Journal of Molecular Biology 284 1391-1398.

Martin J, Dominguez F, Avila S, Castrillo JL, Remohi J, Pellicer A \& Simon C 2002 Human endometrial receptivity: gene regulation. Journal of Reproductive Immunology 55 131-139.

Matsushima-Nishiu M, Unoki M, Ono K, Tsunoda T, Minaguchi T, Kuramoto H, Nishida M, Satoh T, Tanaka T \& Nakamura Y 2001 Growth and gene expression profile analyses of endometrial cancer cells expressing exogenous PTEN. Cancer Research 61 3741-3749.

Meng Y, Wei L \& Wang J 2001 Monitoring gene expression profile changes in endometrial cancer using cDNA microarray technology. Zhonghua Yi Xue Za Zhi 81 665-668.

Mohamed OA, Jonnaert M, Labelle-Dumais C, Kuroda K, Clarke HJ \& Dufort D 2005 Uterine Wnt/\{beta\}-catenin signaling is required for implantation. PNAS 102 8579-8584.

Mutter GL, Baak JP, Fitzgerald JT, Gray R, Neuberg D, Kust GA, Gentleman R, Gullans SR, Wei LJ \& Wilcox M 2001 Global expression changes of constitutive and hormonally regulated genes during endometrial neoplastic transformation. Gynecologic Oncology 83 177-185. 
Nie GY, Li Y, Batten L, Griffiths B, Wang J, Findlay JK \& Salamonsen LA 2000a Uterine expression of alternatively spliced mRNAs of mouse splicing factor SC35 during early pregnancy. Molecular Human Reproduction 6 1131-1139.

Nie GY, Li Y, Hampton AL, Salamonsen LA, Clements JA \& Findlay JK $2000 \mathrm{~b}$ Identification of monoclonal nonspecific suppressor factor beta mNSFbeta as one of the genes differentially expressed at implantation sites compared to interimplantation sites in the mouse uterus. Molecular Reproduction and Development 55 351-363.

Nie GY, Li Y, Wang J, Minoura H, Findlay JK \& Salamonsen LA 2000 c Complex regulation of calcium-binding protein D9k calbindin-D9k in the mouse uterus during early pregnancy and at the site of embryo implantation. Biology of Reproduction 62 27-36.

Nie GY, Li Y, Minoura H, Findlay JK \& Salamonsen LA 2003 Specific and transient up-regulation of proprotein convertase 6 at the site of embryo implantation and identification of a unique transcript in mouse uterus during early pregnancy. Biology of Reproduction 68 439-447.

Noyes RW, Hertig AT \& Rock J 1950 Dating the endometrial biopsy. Fertility and Sterility $13-25$.

Oehler MK, MacKenzie IZ, Wallwiener D, Bicknell R \& Rees MC 2002 Wnt-7a is upregulated by norethisterone in human endometrial epithelial cells: a possible mechanism by which progestogens reduce the risk of estrogen-induced endometrial neoplasia. Cancer Letters 186 75-81.

Okada H, Nakajima T, Yoshimura T, Yasuda K \& Kanzaki H 2003 Microarray analysis of genes controlled by progesterone in human endometrial stromal cells in vitro. Gynecological Endocrinology 17 271-280.

Okada S, Okada H, Sanezumi M, Nakajima T, Yasuda K \& Kanzaki H 2000 Expression of interleukin-15 in human endometrium and decidua. Molecular Human Reproduction 6 75-80.

Okulicz WC, Ace CI \& Torres MS 2003 Gene expression in the rhesus monkey endometrium: differential display and laser capture microdissection. Frontiers in Bioscience 8 d551-d558.

Passey RJ, Williams E, Lichanska AM, Wells C, Hu S, Geczy CL, Little MH \& Hume DA 1999 A null mutation in the inflammationassociated S100 protein S100A8 causes early resorption of the mouse embryo. Journal of Immunology 163 2209-2216.

Ponnampalam AP, Weston GC, Trajstman AC, Susil B \& Rogers PA 2004 Molecular classification of human endometrial cycle stages by transcriptional profiling. Molecular Human Reproduction 10 879-893.

Popovici RM, Kao LC \& Giudice LC 2000 Discovery of new inducible genes in in vitro decidualized human endometrial stromal cells using microarray technology. Endocrinology 141 3510-3513.

Pritchard CC, Hsu L, Delrow J \& Nelson PS 2001 Project normal: defining normal variance in mouse gene expression. PNAS 98 13266-13271.

Reese J, Das SK, Paria BC, Lim H, Song H, Matsumoto H, Knudtson KL, DuBois RN \& Dey SK 2001 Global gene expression analysis to identify molecular markers of uterine receptivity and embryo implantation. Journal of Biological Chemistry 276 44137-44145.

Riesewijk A, Martin J, van Os R, Horcajadas JA, Polman J, Pellicer A, Mosselman S \& Simon C 2003 Gene expression profiling of human endometrial receptivity on days $\mathrm{LH}+2$ versus $\mathrm{LH}+7$ by microarray technology. Molecular Human Reproduction 9 253-264.

Risinger JI, Maxwell GL, Chandramouli GV, Jazaeri A, Aprelikova O, Patterson T, Berchuck A \& Barrett JC 2003 Microarray analysis reveals distinct gene expression profiles among different histologic types of endometrial cancer. Cancer Research 63 6-11.
Sharkey AM, Catalano RD, Evans AL, Charnock-Jones DS \& Smith SK 2005 Novel antiangiogenic agents for use in contraception. Contraception 71 263-271.

Simmons DG \& Kennedy TG 2002 Uterine sensitization-associated gene-1: a novel gene induced within the rat endometrium at the time of uterine receptivity/sensitization for the decidual cell reaction. Biology of Reproduction 67 1638-1645.

Smid-Koopman E, Blok LJ, Kuhne LC, Burger CW, Helmerhorst TJ, Brinkmann AO \& Huikeshoven FJ 2003 Distinct functional differences of human progesterone receptors $A$ and $B$ on gene expression and growth regulation in two endometrial carcinoma cell lines. Journal of the Society for Gynecologic Investigation 10 49-57.

Sompayac L, Jane S, Burn TC, Tenen DG \& Danna KJ 1995 Nucleic Acids Research 23 4738-4739.

Southern EM 1974 Detection of specific sequences amoung DNA fragments separated by gel electrophoresis. Journal of Molecular Biology 98 505-517.

Stafford P \& Liu P 2003 Microarray technology comparison, statistical analysis and experimental design. In Microarrays Methods and Applications- Nuts and Bolts, Ed. G Hardiman. Eagleville, PA, USA: DNA Press.

Tierney EP, Tulac S, Huang ST \& Giudice LC 2003 Activation of the protein kinase A pathway in human endometrial stromal cells reveals sequential categorical gene regulation. Physiological Genomics 16 47-66.

Tulac S, Nayak NR, Kao LC, Van Waes M, Huang J, Lobo S, Germeyer A, Lessey BA, Taylor RN, Suchanek E \& Giudice LC 2003 Identification, characterization, and regulation of the canonical Wnt signaling pathway in human endometrium. Journal of Clinical Endocrinology and Metabolism 88 3860-3866.

Tynan S, Pacia E, Haynes-Johnson D, Lawrence D, D'Andrea MR, Guo JZ, Lundeen S \& Allan G 2005 The putative tumor suppressor deleted in malignant brain tumors 1 DMBT1 is an estrogen-regulated gene in rodent and primate endometrial epithelium. Endocrinology 146 1066-1073.

Wu Y, Kajdacsy-Balla A, Strawn E, Basir Z, Halverson G, Jailwala P, Wang Y, Wang X, Ghosh S \& Guo SW 2006 Transcriptional characterizations of differences between eutopic and ectopic endometrium. Endocrinology 147 232-246.

Yanaihara A, Otsuka Y, Iwasaki S, Aida T, Tachikawa T, Irie T \& Okai T 2005 Differences in gene expression in the proliferative human endometrium. Fertility and Sterility 83 (Supplement 1) 1206-1215.

Yoon SJ, Choi DH, Lee WS, Cha KY, Kim SN \& Lee KA 2004 A molecular basis for embryo apposition at the luminal epithelium. Molecular and Cellular Endocrinology 219 95-104.

Yoshioka K, Matsuda F, Takakura K, Noda Y, Imakawa K \& Sakai S 2000 Determination of genes involved in the process of implantation: application of GeneChip to scan 6500 genes. Biochemical and Biophysical Research Communications 272 531-538.

Zhou HJ, Shi YF, Li JQ \& Cui JQ 2003 Preliminary study on gene expression profile of endometrial adenocarcinoma. Zhonghua Zhong Liu Za Zhi [Chinese Journal of Oncology] 25 464-467.

Received 23 July 2005

First decision 14 September 2005

Revised manuscript received 14 March 2006

Accepted 24 March 2006 